\title{
Celtic Roots Amidst the Fern: Irish-Scottish Studies in New Zealand ${ }^{*}$
}

BRAD PATTERSON

Victoria University of Wellington

In July 2000, at the first-ever academic conference focusing on the experiences of the New Zealand Irish, novelist-historian and sometime international opera singer Edmund Bohan made an impassioned plea for greater recognition of the Irish and Scottish contributions to the nation's historical development. ${ }^{1}$ New Zealand's history, he claimed, had been hijacked by those of English descent. For more than 100 years an Anglocentric tradition had dominated New Zealand's historiography. Scholars as distinguished as J.C. Beaglehole and Sir Keith Sinclair had found no place in their recountings for rival ethnic traditions, for divisions within a monolithic settler society. Returning to New Zealand in the late 1980s, after an absence of nearly 30 years, Bohan had been nonplussed by an almost obsessive belief that it was essentially a bicultural society, one made up of Maori on the one hand and Pakeha (the rest, mainly transplanted Britons) on the other. Bohan knew from personal experience that things were far more complicated than that:

with two Gaelic-speaking Irish Catholic grandparents and two Gaelicspeaking Highland Scottish Presbyterian grandparents . . . I was reared in a dual tradition of Irish and Highland Scottish nationalism. Our family refought the Reformation every Sunday morning, until a vast lunch and the power of music soothed our savage breasts. The curse of Cromwell, the struggle for Irish Home Rule, the disaster of Culloden and the iniquity of the Highland Clearances all resonated powerfully throughout my young . . . [New Zealand] . . life.'

Even allowing for a degree of dramatisation, Bohan's reaction is far from unique. A recent estimate has it that probably upwards of one quarter of New Zealand's current population of four million is descended from migrants who lived their early lives in Ireland or Scotland. ${ }^{3}$ If this scarcely makes New Zealand a Celtic nation, it nevertheless makes it one where sturdy Celtic roots are intricately intertwined with the indigenous fern rhizomes, not to mention the suckers and runners from introductions from other parts. At

Text of paper presented to AHRB Diaspora Seminar, University of Aberdeen, 21 October 2003. Subsequent developments are elaborated in footnotes. 
a time when people worldwide are expressing increasing interest in their roots, it is arguable that those set in New Zealand's soil should also be carefully uncovered.

\section{The Scale of Irish and Scottish Migration to New Zealand}

It is generally agreed, if admittedly on the basis of still fragmentary research, that migration from Ireland and Scotland to New Zealand was especially important between the years 1840 (when United Kingdom sovereignty was reluctantly established) and 1936 (when the Empire Settlement Act ran its course). ${ }^{4}$ Precise numbers, however, are missing. An estimate for the Scots - by Tom Brooking - is that roughly 117,000 migrated to New Zealand over that period. ${ }^{5}$ Donald Akenson has suggested that in the region of 100,000 Irish over the same period would be a fair guestimate. ${ }^{6}$ These may seem comparatively small totals, but consider that by 1900 the total European population of New Zealand was still barely 770,000; and even by 1936 less than 1.5 million. $^{7}$ New Zealand possibly had to work the hardest of all the settler societies to attract migrants from the home countries. It was far away; the costs of travel were high; it had a reputation as a wild and dangerous place.

It soon may be possible to present much better data. In the mid-1990s, with substantial public funding, New Zealand's Ministry of Culture and Heritage History Group launched a major research project ('The Peopling of New Zealand') on the origins of migrants from Britain and Ireland, roughly from 1800 to $1945 .{ }^{8}$ Between 1996-2000, under the supervision of then Chief Historian, Jock Phillips, historical geographer Terry Hearn, formerly of the University of Otago, assisted by Nicholas Bayley, developed a research strategy and analysed collected data. As the project proposal stated, the aim was to:

explore the notion that Pakeha - and in part New Zealand identity can only be understood by finding out more about who actually did migrate to New Zealand. ${ }^{9}$

Among key questions to be addressed by the research were:

- Just who were the ancestors of New Zealand's European majority?

- Where did the migrants come from (if possible down to county level)?

- When did they arrive in the country?

- What can be established about their occupational, religious and family backgrounds?

The answers were primarily sought through the scientific sampling and study of death registers, but with recourse to other sources, such as shipping and military service records. While it is intended to release the findings in book 
form, it has been recently indicated that, in addition to broad findings being made available on a website, it is now proposed that the raw data be also made available in electronic form. ${ }^{10}$ In due course this will be a boon to researchers in many disciplines.

In the meantime, there are few alternatives to making do with what is available. Broad patterns, at least, are suggested by the published census figures. ${ }^{11}$ If the gains from net migration are graphed against those from natural increase over time, those periods when migration was of greatest significance in population building stand out. (Fig. 1). There were two major peaks. The first, in the early and mid-1860s, demonstrates the impact of gold discoveries and war with the Maori. Between 1861-65 miners flowed into New Zealand in profusion. At the same time, nearly 2000 soldiers took their discharges from Imperial regiments, while another 6000 were recruited as military settlers. The second, in the early 1870 s, reflects the assisted immigrants brought out as part of Julius Vogel's public works and closer settlement schemes. There are also discernible minor peaks, periods when the net inflow consistently exceeded 20,000 per annum. There is a surge in the early 1900s, the outcome of more intensive farming, with linked demands for labour, both on the land and in processing. There is another in the early and mid-1920s, the aftermath of World War One. After World War Two there were sustained inflows as New Zealand strove to diversify its economic base.

Figure 1 - Contributions of migration and natural increase to growth of non-Maori population

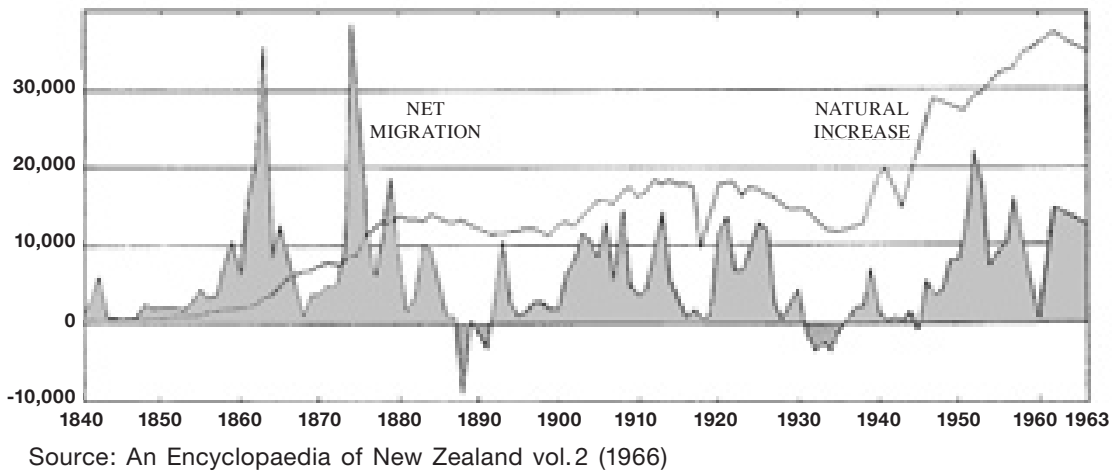

What an overview of population building does not illuminate is just how many of the migrants were from Ireland, and how many from Scotland. As a broad generalisation, around 90 per cent of all those reaching New Zealand's shores, certainly until 1945, were born in Britain and Ireland. Preliminary figures supplied by the Ministry of Culture and Heritage 
give at least some indication of the individual contributions by "Atlantic Archipelago' countries until 1914. ${ }^{12}$ (Fig. 2) They suggest that England was the prime migrant source throughout, providing around two-thirds of all migrants in the first colonising decade, slipping to around half in 1860 s and 1870 s, then returning to 1840 s levels in the later decades of the nineteenth century. There was a further revival in the immediate pre-World War One years. Scotland was always a more constant supplier of people, averaging just under one quarter of all migrants in each decade to 1914. In contrast, Irish migration tended to be 'bunched', to be heavily concentrated in the two major nineteenth century net migration peaks earlier identified. In the 1860s and 1870s Ireland supplied between a fifth and a quarter of all migrants, at other times upwards of a tenth of all arrivals. Curiously, Welsh migration barely registered in the returns.

Figure 2: Migrants from Britain \& Ireland to 1914 by Country of Origin

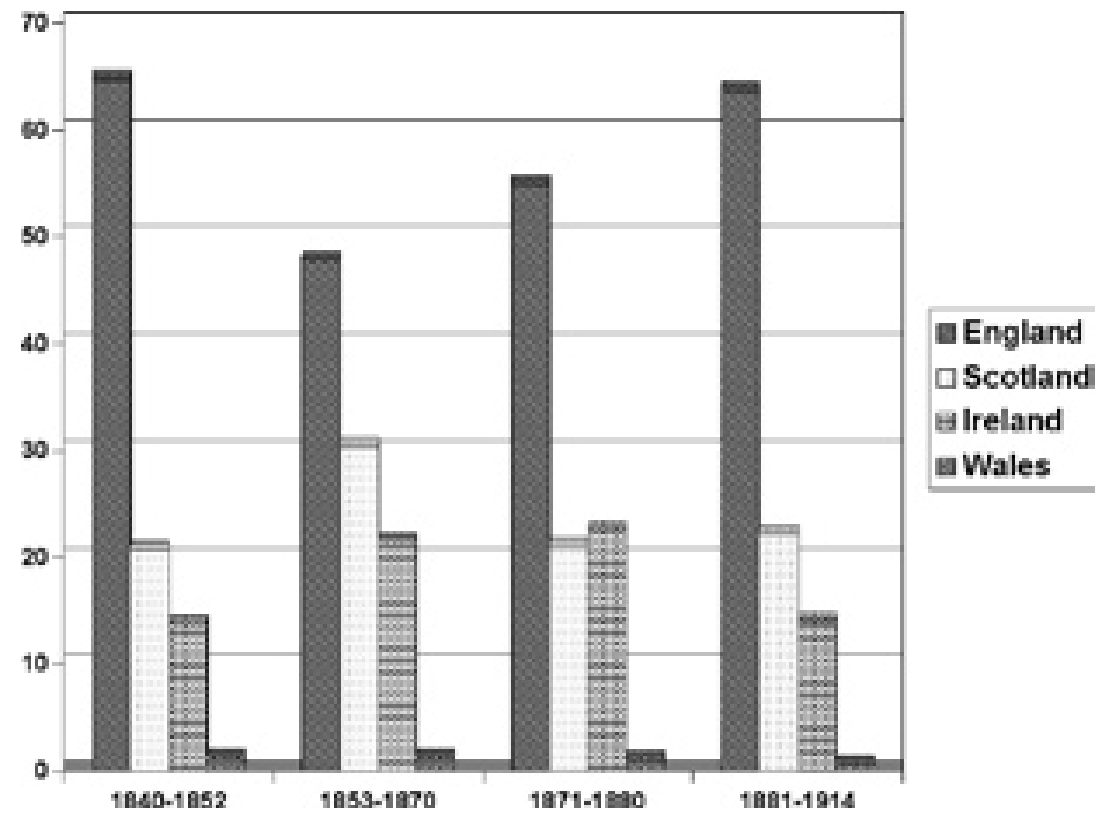

Source: Peopling of New Zealand Project (Ministry of Culture \& Heritage

The preliminary results of 'The Peopling of New Zealand' project are also suggestive in respect of the particular parts of Scotland and Ireland from which New Zealand's migrants tended to be drawn. ${ }^{13}$ (Fig. 3a \& b). In the case of Ireland, Leinster provided the first influx, but Ulster became the most consistent supply source, accounting for more than half of all Irish migrants in the two decades up to World War One. For most of the 
Celtic Roots Amidst the Fern: Irish-Scottish Studies in New Zealand

Figure 3a: Regional Origins of Irish Migrants (\%)

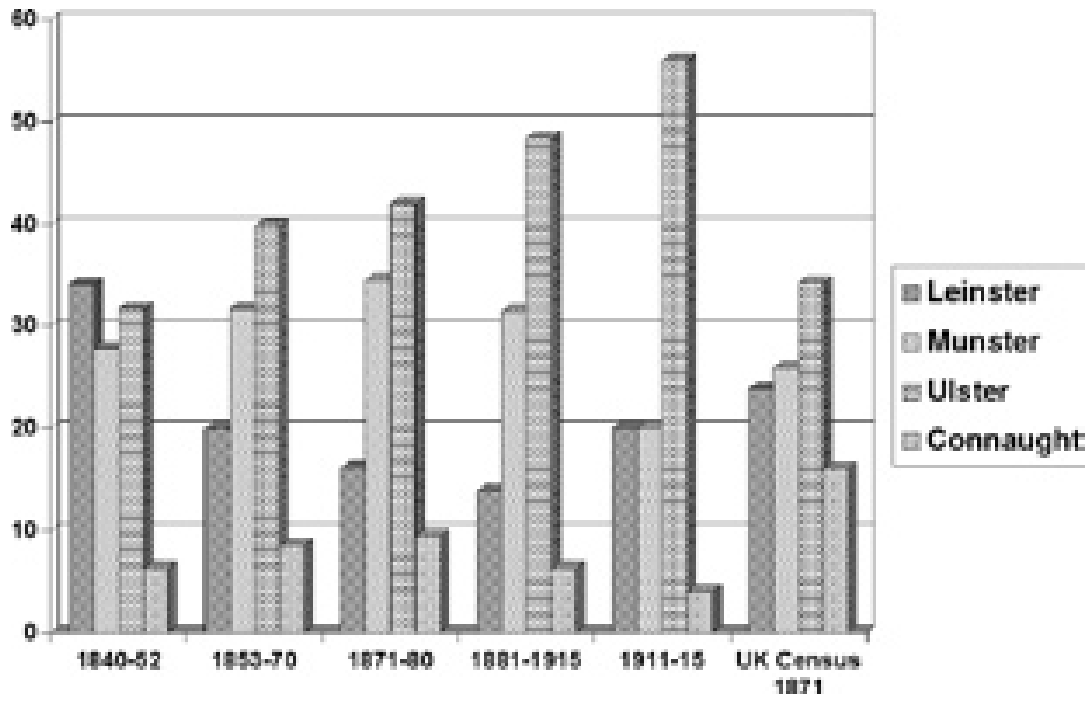

Source: Peopling of New Zealand Project (Ministry of Culture \& Heritage)

Figure 3b: Regional Origins of Scots Migrants (\%)

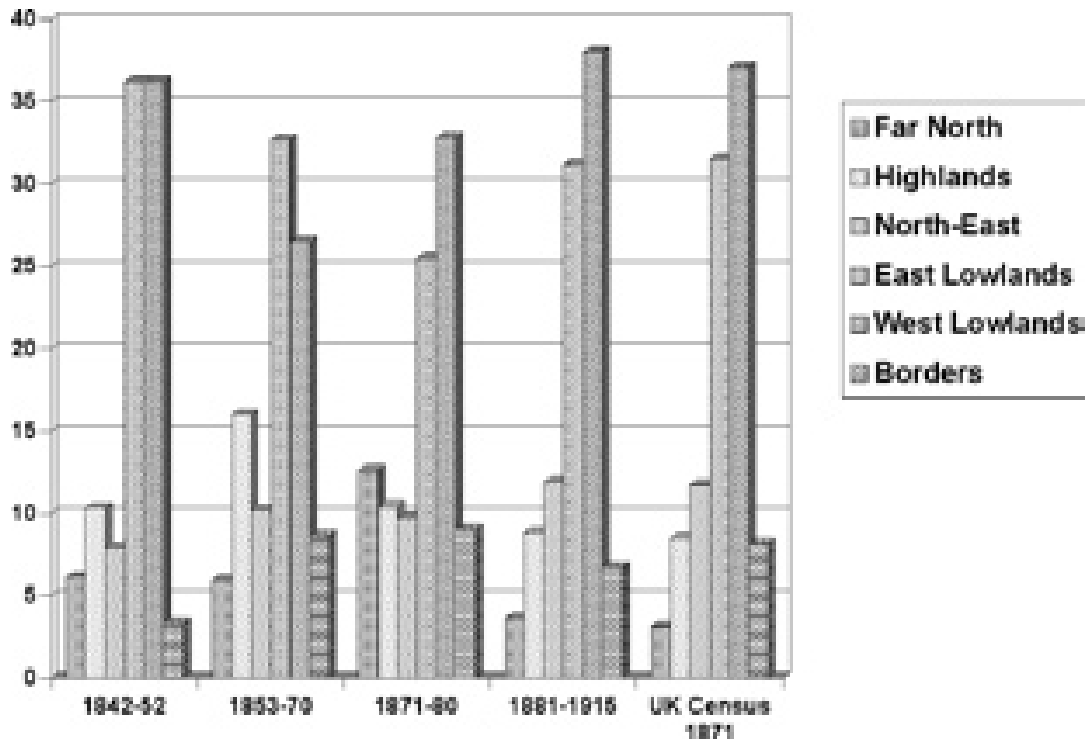

Source: Peopling New Zealand Project (Ministry of Culture \& Heritage) 
nineteenth century Munster was the most significant secondary source of migrants, accounting for up to one third of Irish migrants. Connaught was never a significant source of migrants to New Zealand. With respect to the Scots, the possibly predictable finding is that the great majority of those coming to New Zealand were from the Lowlands. Highlanders averaged only around one tenth of all Scottish migrants over the seven decades to 1914 . The 1870s minor escalation in migration from the Far North was heavily weighted towards off-shore islanders, especially Shetlanders.

While the research team also collected data on the New Zealand destinations of migrants, so far only the results for one year (1871) have been released. As earlier suggested, the Ministry project also compiled datasets on migrant religious allegiances and occupations, but these are not germane to the present paper. Although some reservations have been expressed about how the data was collected, there is surely sufficient statistical evidence to reinforce a critical point: the Irish and Scottish contributed significantly to the settlement of New Zealand. The question then becomes: have the distinctive contributions of these two ethnic groups been adequately recorded? In short, was Bohan right? Have adequate histories of the Irish and the Scots in New Zealand still to be written?

\section{The Historiography of the New Zealand Irish and Scots}

As a starting point in addressing the above questions, several systematic library catalogue searches were undertaken. The first surveyed holdings listed in Victoria University's electronic catalogue. ${ }^{14}$ Searching under the headings 'Irish-New Zealand' and 'Scots-New Zealand', totals of 23 and 35 items respectively were turned up. Even acknowledging the crudeness of the measure, from this result it may be concluded that the volume of publishing has not been substantial, and closer examination reveals that neither has the quality been especially high. By far the most prolific publishers on the Celtic migrants have been family historians and, notwithstanding several model studies of the genre, the great majority of the publications tend more to be lists of begattings. As a cross-check, the catalogues of the National Library of New Zealand were also searched, the same subject headings being utilised. ${ }^{15}$ At first it appeared the yield might be more bountiful. Some 81 items appeared under 'Irish-New Zealand', but again disappointment was in store: 17 were found to have no direct relationship to New Zealand at all; there were another 31 family histories not held by the university; much of the remainder was ephemera. The 72 items listed under 'Scots-New Zealand' were equally disappointing. For more than 160 years of European settlement history, the haul is amazingly meagre.

Lest it be thought that the researchers of New Zealand's family histories are being scorned or discounted, it must be stated categorically this is 
not the case. Genealogists have been a very positive force in preserving and popularising New Zealand's history, and have much to contribute to future, hopefully more innovative, studies in New Zealand ethnic history. Indeed, a number of the family histories located in the searches will add texture to the quantitative studies in progress or planned. It is imperative, however, that family or individual case studies be collated within contextual frameworks established through wider-ranging projects. The point of the catalogue searches was to assess the extent of monograph research and writing on the New Zealand Irish and Scots. On the basis of what the searches turned up, two broad observations may be made: firstly, such serious writing as exists has been largely confined to the last dozen years; and secondly, notwithstanding the fact that there have been more Scots than Irish migrants, recording the history of the Scots in New Zealand is even more underdeveloped than that of the Irish. While these observations refer primarily to the monograph literature, a parallel search of serials indexes suggested comparable patterns.

It is nevertheless useful to turn to what has been written, and to attempt to identify some of the more important studies. In respect of the New Zealand Irish, serious scholarly writing may be classified as either pre-DHA or post-DHA; in other words, either pre- or post-Donald Harman Akenson's ground-breaking Half the World from Home: Perspectives on the Irish in New Zealand, 1860-1950, published in 1990. ${ }^{16}$ Pre-Akenson there were occasional biographies, possibly the most notable being Timothy McIvor's The Rainmaker ${ }^{17}$ (a biography of Ulster-born Premier John Ballance), scattered journal articles, and a few local histories, for instance A.J. Gray's An Ulster Plantation: the Story of the Katikati Settlement,${ }^{18}$ first published as far back as 1938. The only attempt at an overview was Richard P. Davis' 1974 book Irish Issues in New Zealand Politics, 1868-1922, ${ }^{19}$ a revision of his Otago University doctoral thesis. Sadly, the importance of this pioneering study has tended to be overlooked, perhaps because of differences that developed between the author and Australasia's leading scholar in the field. Davis subsequently went on to write more about the colonial Irish, but from Tasmania, and primarily about those transported to the penal colony. Only recently, in retirement, has he returned to New Zealand research.

It is not too much to claim that Akenson's 1990 contribution has been a catalyst for much recent work on the New Zealand Irish - not all of it, but much of it. His involvement arose from research for his earlier book Small Differences,${ }^{20}$ he then finding the sum total of the New Zealand scholarly literature to be (in his own words) 'one significant monograph' (Davis) and 'a few fugitive articles'. Unusually, Akenson set about at least partially remedying the deficiency himself, taking up the John David Stout Research Fellowship at Victoria University's Stout Research Centre in 1988. Akenson 
did not set out to write an authoritative history of the New Zealand Irish. Instead, he offered a sophisticated sampler of some techniques that could be employed by scholars engaging with this form of ethnic history. He also suggested a research agenda, something that will be returned to presently.

Quite serendipitously, in addition to Half the World From Home, 1990 also saw the publication of several other important contributions on the New Zealand Irish. Most enchanting was Patrick O'Farrell's part historypart personal memoir Vanished Kingdoms: Irish in Australia and New Zealand ${ }^{21}$ later described by Akenson as 'an amazing, high-risk book that works: an interlayering of personal memories, family history, big historical questions and reflections on the Irish in the antipodes'. ${ }^{22}$ (O'Farrell, the doyen of historians of the Australian Irish, but a New Zealander by birth, also incidentally contributed part chapters on the New Zealand Irish to Volumes $\mathrm{V}$ and VI of the New History of Ireland..$^{23}$ ) Also promising in that year was Charlotte Macdonald's A Woman of Good Character. Single Women as Immigrant Settlers in Nineteenth Century New Zealand, ${ }^{24}$ which looked closely at those drawn from Ireland and Scotland. Macdonald, however, has subsequently chosen to move to other fields.

From the mid-1990s a slow trickle of relevant books began to appear (although, curiously, not all appear to have been classified as 'Irish-New Zealand' by the librarians). Most prolific was Edmund Bohan, the earlier noted critic of New Zealand's Anglocentric historiographical tradition. Bohan has made the New Zealand Anglo-Irish his particular field, publishing three generally well-received biographies: Edward Stafford. New Zealand's First Statesman ${ }^{25}$ in 1994, Blest Madman: FitzGerald of Canterbury ${ }^{26}$ four years later, and a new biography of Sir George Grey, To Be a Hero, ${ }^{27}$ in the same year. He has combined this formidable output of political biography with a stream of New Zealand-set historical novels featuring Irish detective Inspector O'Rourke. In 1995 New Zealand's foremost business historian, Russell Stone, published a biography of James Dilworth, ${ }^{28}$ a nineteenthcentury Ulster-born Auckland entrepreneur, a book which it is claimed opens new lines of inquiry into the role of Ulster Irish in New Zealand business. Then, in 1996, Anna Rogers produced the first popular history of the New Zealand Irish, A Lucky Landing, ${ }^{29}$ a book with more than passing resemblance to Tim Pat Coogan's Wherever Green is Worn.

In 1997, two books broke new ground - they merit special comment. First was Rory Sweetman's Bishop in the Dock: The Sedition Trial of James Liston, ${ }^{30}$ an account of the prosecution in 1922 of the coadjutor Bishop of Auckland for pro-Irish nationalist comments at that year's St Patrick's Day celebrations. Through this mechanism the author deftly explores sectarianism in early twentieth-century New Zealand. For more than a decade Sweetman has been New Zealand's leading historian of Irish Catholicism, also 
publishing books on the integration of Catholic schools into the state system and the Hibernians. ${ }^{31} \mathrm{He}$ is currently moving to a study of the Orange Order in New Zealand, an interesting juxtaposition with his previous work. The second notable book in 1997 was Lyndon Fraser's To Tara via Holyhead: Irish Catholic Immigrants in Nineteenth-Century Christchurch..$^{32}$ Based on a $1994 \mathrm{PhD}$, it shows how the migrants adjusted imaginatively and creatively to their new environment by forging durable social networks based on ethnic ties. Drawing comparison with North American experiences, historian turned sociologist Fraser looks at issues of kinship and community in quite new ways.

To conclude this brief survey of recent writing on the New Zealand Irish, two more books published since 2000, both edited collections of essays, may be noted. They have much in common, including no less than seven of the contributors! Lyndon Fraser's A Distant Shore. Irish Migration and New Zealand Settlement ${ }^{33}$ focuses specifically on Irish migration to New Zealand, the processes and the immediate consequences. It is, its editor states, 'a collaborative venture that pulls together exciting new work by a small band of writers with an interest in the Irish disapora'. The aim is to shed light on 'the great chains of mobility that tied New Zealand to various points of origin in Ireland'. My own volume, The Irish in New Zealand: Historical Contexts and Perspectives, ${ }^{34}$ is wider ranging. With Akenson's Half the World from Home already regarded as a classic of New Zealand ethnic literature, it was deemed appropriate in 2000 to invite the author back to participate in a stocktake of the state of New Zealand Irish Studies ten years on. Most of the papers in Irish in New Zealand had their first airings at that conference.

Beyond recording the most recent thinking of old hands such as Akenson and O'Farrell, beyond rekindling the interests of scholars now better known in other fields (for example, Hugh Laracy and Vincent O'Sullivan), the significance of the two volumes is that they have brought to public attention a number of new names. More will be heard more in future, much more, not only from younger scholars such as Fraser and Sweetman, but also Angela McCarthy, Alasdair Galbraith, Sean Brosnahan, and Kevin Molloy. It was a struggle when organising the conference upon which Irish in New Zealand is based, to find thirteen local paper presenters. Two years later, for a second conference, papers on the New Zealand Irish had to be turned down. There is every sign that the scholarly literature on the New Zealand Irish will be greatly augmented in the next decade.

Sadly, it is hard to be as confident about the immediate future of New Zealand Scottish Studies, certainly in the absence of positive intervention. The field of New Zealand Scottish Studies has yet to throw up its catalyst, its Akenson. Probably the nearest candidate has been Tom Brooking of the 
University of Otago, who (with Jennie Coleman) has recently produced a collection similar to those on the Irish just discussed: The Heather and the Fern: Scottish Migration and the New Zealand Settlement. ${ }^{35}$ No disrespect to Brooking is intended when it is observed that the book was delayed for some years as he sought sufficient essays, that one-third of the papers eventually published are by overseas specialists, and that two other papers are by scholars hitherto better known for their writings on the New Zealand Irish. Bringing the book out was a battle. His tenacity can only be admired. Brooking has shown the same tenaciousness for the better part of 30 years, labouring largely alone on the New Zealand Scots as other commitments have allowed. His 1984 biography of the founder of the Otago settlement, William Cargill, And Captain of their Souls, ${ }^{36}$ was followed in 1985 by an important essay in R. A. Cage's The Scots Abroad. ${ }^{37}$ It remains the best brief survey of the Scots in New Zealand. Ten years later, in 1996, Brooking published what is generally considered to be his most important book to date, Lands for the People: The Highland Clearances and the Colonization of New Zealand, a biography of John McKenzie..$^{38}$ This study of New Zealand's late nineteenth-century reforming Lands Minister was over 25 years in the making.

Beyond Brooking's ongoing contributions, there has not been a whole lot else. To be sure, in addition to the family histories and ephemera, by dint of boundary stretching it is possible to include books such as Jim McAloon's award winning study of the nineteenth-century South Island wealthy, ${ }^{39}$ or Bassett and King's biography of war-time Prime Minister Peter Fraser ${ }^{40}$ but the 'Scottishness' of the subjects, collective or individual, is incidental to the book themes. G.L. Pearce's The Scots of New Zealand, ${ }^{41}$ published in 1976 , is the only popular history so far produced. There would certainly be a place for a more soundly-based successor. Mention, however, must be made of two community studies published during the 1990s. In 1991 Maureen Molloy's Those Who Speak to the Heart: The Nova Scotia Scots at Waipu, 1854-1920 42 appeared. Also a rewrite of a PhD thesis, this may be regarded as the best work on the Rev Norman McLeod's founding of a Highland settlement in the north of the North Island in 1865, after first establishing in Nova Scotia and Australia. The epic story has attracted a number of writers, including novelist Fiona Kidman, but there is a growing feeling that it has now been almost done to death. The second book is freelance historian Susan Butterworth's Chips off the Auld Rock. Shetlanders in New Zealand. ${ }^{43}$ Commissioned to commemorate the Wellington Shetland Society's 75th anniversary in 1987, and inevitably hagiographical to a degree, it is nevertheless a superior example of the genre.

Given the obvious historiographical void, the most hopeful recent development is the expressed determination of a small group of mainly 
New Zealand-based scholars, several still relatively early in their careers, to initiate a major new research project on the New Zealand Scots, one which would accurately establish the dimensions and patterns of migration over time, as well as assessing impacts (possibly both for New Zealand and Scotland). There have already been several meetings to discuss the feasibility of such a project, and the reactions so far have been wholly positive. There is a strong inclination to positively engage with interested historians in Scotland. Should the project proceed, it could be the sort of positive intervention - academic affirmative action - needed to kick-start deeper research into the story of the New Zealand Scots. ${ }^{44}$

Clearly, considerably more research needs to be done, in respect of the Irish as well as the Scots. Helpfully both Akenson and Brooking have publicly outlined research agendas. ${ }^{45}$ With these having been set down 12 years apart, it is instructive to note the similarities as well as the differences. (Table 1) The 2000 stocktake of progress in New Zealand Irish Studies revealed that there had been a number of advances in the decade since Akenson's agenda was presented. Some of the new research had already made its way into print, and there are still unpublished findings in post-graduate theses. Two of the glaring gaps remaining appear to be studies of Irish/Maori relations and the New Zealand experiences of Irish women. With Brooking's prescription having been written only in 2002, there will be no surprise that there have been as yet few inroads.

Table 1 - New Zealand Irish-Scottish studies. Research agendas

Irish

(Akenson - 1990)

1. Ethnic identity

2. Demographic analysis

3. Institutional/organisational history

4. Biography/biographies

5. Relations with Maori

6. Religious history

7. Women

8. Local and community studies

9. Literature

\section{Scottish}

(Brooking - 2002)

1. Ethnic identity

2. Demographic analysis

3. Institutional/organisational history

4. Biography/biographies

5. Relations with Maori

6. Religious history

7. Women
8. Folkways

9. Genealogies

10. Environment/landscape

11. International comparative studies

\section{Fostering Irish-Scottish Research: The University Environment}

While there must always be scope, and encouragement, for the independent writer, it is likely in the present world that most of the research gaps identified will be filled - if they are to be filled at all - by research 
undertaken within or in association with New Zealand's universities, whether by staff, research fellows (paid or unpaid), or post-graduate students. It is therefore appropriate to turn briefly to the treatment of Irish-Scottish Studies - or, more frequently Irish and/or Scottish Studies - in the universities.

In the light of demonstrable popular New Zealand interest in Celtic culture (admittedly, principally Irish) - whether through fondness for ethnic music and dance, merely through the patronage of theme pubs, or through sales of such books as have been published, a burgeoning of tertiary course offerings might be anticipated. This is scarcely the case. In 2004, only a small number of courses are being offered. (Table $2{ }^{46}$. Several clear points emerge. With the exception of Victoria University's summer school on 'The Irish and the Scots in Australasia', to be taught for the first time in 2004/05, there are no undergraduate level papers focusing on the diasporas. There are, however, two comparative papers currently being offered at the Honours level, one in Auckland's History Department, the other under the umbrella of sociology at Canterbury. At this point only Auckland University consistently offers courses at both the undergraduate and post-graduate levels. In all of the universities, whether the papers offered be in history, the social sciences, or languages and literature, the overwhelming emphasis continues to be on the Irish.

Table 2 - New Zealand Irish-scottish Studies. Tertiary Courses 2004

\section{Auckland}

Post-grad $\quad\left\{\begin{array}{l}\text { HIST } 717 \text { The Irish in North America, Australia and New Zealand } \\ \text { ENG } 734 \text { Irish Literature and Politics } \\ \text { ENG } 714 \text { Modern Irish Writers }\end{array}\right.$

Undergrad HIST 365 Ireland since 1798

\section{Waikato}

Post-grad ENG 514 Scottish Literature

Undergrad $\left\{\begin{array}{l}\text { HIST } 241 \text { Introduction to Irish History } \\ \text { HIST } 121 \text { Founding Peoples of Britain \& Ireland } \\ \text { ENG } 224 \text { Irish \& Scottish Literature: An Introduction }\end{array}\right.$

Victoria

Post-grad None

Under-grad FHSS The Irish \& Scots in Australasia

\section{Canterbury}

Post-grad SOC 428 Diaspora, Migration, Identities

Undergrad HIST 360 British Isles Rebellions in the 18th Century

\section{AUT, Massey, Lincoln, Otago}

No courses at undergraduate or post-graduate levels 
Looking to the immediate future, there is both good and bad news. Building on its proposed summer school, Victoria University hopes soon to offer a multidisciplinary post-graduate paper in Irish-Scottish studies. ${ }^{47}$ There are also currently proposals for the establishment of chairs in Celtic/Irish Studies at both the Universities of Auckland and Otago, although how far the proposals have progressed is unclear. ${ }^{48}$ Less positively, there are question marks over the future of 'Scottish and Irish Studies' at the University of Waikato. Although in 2002 a clutch of courses was approved for an undergraduate major in 'Scottish and Irish Studies', the majority will not actually be taught in 2004. ${ }^{49}$ Interested staff members moving on and lukewarm administrative support have both taken their toll.

Another measure of university commitment to the promotion of Irish and Scottish Studies is the extent of supervised post-graduate research being undertaken in departments. While there are occasional thesis presentations in other disciplines, those presented in history provide a ready yardstick. ${ }^{50}$ (Table 3) At first glance the returns for twelve years seem meagre: two $\mathrm{PhDs}$, twelve masterates, thirteen honours research essays. And, on one level, the preliminary assessment would be true. In New Zealand's largest history department, Auckland, two PhDs, eleven masterates and two honours essays were presented in 2002 alone. In the same year, at the much smaller Otago University, five PhDs, four masterates and seventeen honours essays were presented in History. What has to be remembered is that in the existing history departments, for that matter in any discipline, Irish and/or Scottish Studies tend to be but one staff specialism amongst many. There is at present no department, no Chair, specialising in these areas. At only one university, Auckland, is there more than a single staff member, in any department, with active interests in these areas. Further, no single staff member in any mainline department has the luxury of teaching Irish and/or Scottish Studies alone.

Table 3 - New Zealand Irish-scottish Studies Post-graduate Dissertations 1990-2002. History

$\begin{array}{lccc}\text { University } & \text { PhD } & \text { MA } & \text { Hons Essay } \\ \text { Auckland } & - & 5 & 8 \\ \text { AUT } & - & - & - \\ \text { Waikato } & - & 1 & - \\ \text { Massey } & - & 1 & 1 \\ \text { Victoria } & - & - & 1 \\ \text { Canterbury } & 1 & 3 & - \\ \text { Lincoln } & - & - & - \\ \text { Otago } & 1 & 2 & 3 \\ \text { Total } & \mathbf{2} & \mathbf{1 2} & \mathbf{1 3}\end{array}$


In such circumstances the efforts of, for example, Malcolm Campbell at Auckland, or Tom Brooking at Otago, in getting valuable research under way, can only be applauded. In passing, it should be noted that a number of post-graduate students who began their studies in New Zealand departments later went on to take New Zealand-oriented higher degrees, with Irish or Scottish emphases, at universities in the United Kingdom and Ireland. Examples include Rosalind McLean (now teaching at Waikato University) who gained a PhD from Edinburgh in 1990, and Angela McCarthy, who graduated from Trinity College, Dublin, 10 years later. ${ }^{51}$

\section{Victoria University's 'Irish-Scottish Studies Programme'}

It is perhaps appropriate to conclude by referring to an initiative which it is hoped will significantly boost Irish-Scottish Studies in New Zealand over the next few years: the establishment of Victoria University of Wellington's 'Irish-Scottish Studies Programme' (ISSP). This formally came into being on 1 July 2003 and is still a modest enterprise. ${ }^{52}$ Its staffing is thin, restricted to a Director, two honorary fellows, several adjuncts, and part-time administrative assistance. Its budget is small, and there are strong expectations the Director will secure external funding. Though the Director has a relatively free hand in developing the Programme, it is administratively an integral part of the university's Stout Research Centre for New Zealand Studies The key points, however, are that the Programme now exists, and, in modern management-speak, that its 'core business' is Irish-Scottish Studies.

There are several obvious questions: why now; why at Victoria University (rather than, say, Auckland or Otago); and why, in the first instance, attached to a Centre for New Zealand Studies? In many ways, the answers are interlinked. There are both symbolic and practical reasons for the Stout Research Centre acting as an incubator for Irish-Scottish studies in New Zealand. ${ }^{53}$ Honouring the memory of Shetlander Sir Robert Stout, a former Premier and Chief Justice, and first Chancellor of Victoria University College, the Centre was set up in 1984 to 'encourage scholarly inquiry into New Zealand society, history and culture'. It has done that successfully for nearly two decades. The Centre hosts visiting Research Fellows, organises major conferences and workshops, hosts a weekly research seminar, publishes monographs and occasional papers, and brings out the Journal of New Zealand Studies. The Centre has long supervised PhD candidates, and since 2000 has offered a research-based degree, the Masters in New Zealand Studies. A supporting infrastructure is thus already in place. The Stout has also had a long-standing interest in the New Zealand Irish. This commenced with Akenson's tenure of the J.D. Stout Fellowship in 1988/99 and has consolidated during Vincent O'Sullivan's term as Stout Director 
(1997-2000) and since the writer's appointment as Hon. Senior Research Fellow in the mid-1990s. It was wholly in keeping with this interest that the Stout Research Centre should host the Irish in New Zealand conference in 2000, and that Akenson should afford support through several visits.

Although the initial intentions were modest, the success of the 2000 conference caught a building wave. ${ }^{54}$ Almost contemporaneously, Elizabeth Malcolm took up the first Chair in Irish Studies in Australasia, at the University of Melbourne. From the outset there was close co-operation, links also being forged with Melbourne historians with strong interests in Scottish migration. Thus, when a second conference was proposed for 2002, it became almost inevitable that the ethnic compass should widen, as also the areal coverage. The result was a three-day gathering, Celtic Connections: Irish-Scottish Studies Down Under, in October 2002. ${ }^{55}$ This further expansion of horizons was strongly supported by Tom Devine of the University of Aberdeen and Brian Graham from the University of Ulster. Unable to be present in person, both provided video addresses, then participated in a telephone hook-up to the conference. The session was a conference highlight. In the course of the conference an informal meeting between the conference organiser, leading New Zealand researchers, and several overseas visitors, resolved that an attempt should be made to place Irish-Scottish Studies on more secure foundations. It would be fair to claim that two successful major conferences, the publication of a book, and the prospect of another, all in a little over two years, helped create a favourable environment at Victoria. As frequently happens, however serendipity also played a part. A new Vice-Chancellor was appointed in 2002: youngish, innovative, also a second-generation Scot and proud of his heritage. A new ProVice-Chancellor/Maori was also appointed, and his whakapapa (or genealogy) has a strong Scots line. Both participated enthusiastically, and in the case of the latter, emotionally, in the 2002 conference. With the support of the present Director of the Stout Research Centre, Lydia Wevers, a business case was put together in the early months of 2003, the proposal being formally approved by the Vice-Chancellor in May.

As with most modern entities, the Programme has its vision and mission, as well as a three-year plan..$^{56}$ With colleague recognition being imperative, the vision is much as might be expected:

The Irish-Scottish Studies Programme at Victoria University of Wellington is recognised nationally and internationally as a centre of excellence for research in the field.

The mission tells a little more about the role intended:

The establishment of a defined and supported interdisciplinary IrishScottish/Celtic Studies Programme at Victoria University of Wellington, 
thereby providing a national and international focus for the promotion of post-graduate studies and scholarly research into the New Zealand and Australasian Irish-Scottish migrant experiences.

What does all this mean in practice?

One of the Programme's objectives is to co-ordinate the previously inchoate; in a sense to promote more effective divisions of academic labour. The Stout Research Centre, for instance, is better equipped to host conferences than most standard university departments. Its location in Wellington, in close proximity to national research institutions (Archives New Zealand, Alexander Turnbull Library), makes it a handy base for visiting researchers. Its emphasis on research provides a nurturing environment. For a co-ordinating role to be feasible, however, support from as wide a range of interested institutions, organisations and individuals as possible is imperative. Hence each of the other New Zealand universities was personally visited in the first two months of the programme's existence, the message being 'let's collaborate, not compete'. To date the message appears to be well received, in most instances enthusiastically. There has also been consultation with other 'stakeholders': the Irish Ambassador in Canberra, the Irish Consul General, representatives of the British Council, community interest groups. To reinforce the mutual assistance theme, the appointment of an Advisory Committee is being considered ${ }^{57}$ It could include representatives from other universities, as well as influential interested community figures. (The latter are essential when a Programme is expected to raise substantial funding.) The appointment of an international advisory panel is also under consideration. It is intended the Programme will host a website publicising news and events of interest and providing electronic links to others working in the field in New Zealand and co-operating centres overseas. An electronic newsletter, a logical extension, is also under consideration.

The promotion of formal links and exchanges with like research units world-wide is a second task specified in the Director's position description. ${ }^{58}$ A solid working relationship with the University of Melbourne has already developed and there have been regular informal discussions with individuals in many places. The present visit to the northern hemisphere provides opportunities for the opening of dialogue with units in a number of universities. It is hosted by the University of Ulster, but an invitation to divert to Aberdeen was warmly received, and it is anticipated that there will be discussions at a half dozen other universities. Quite how co-operation internationally may be encouraged is something open for discussion. Obvious possibilities might include: sharing in programme development; collaboration in research projects; the hosting of Visiting Fellows, and senior student exchanges. The arrangements may differ from case to case. 
Almost certainly the ISSP Director's greatest responsibility in the immediate future will be the formulation, hosting and supervision of major research projects, principally with external funding. ${ }^{59}$ Putting together proposals is relatively straightforward, financing them much the more difficult. In New Zealand, government funding for what is deemed 'curiosity' research is extremely limited, largely confined to the Royal Society of New Zealand's Marsden Fund. Bidding for limited means is intense. A funding application for the team project on Scottish migration to New Zealand is currently being prepared under Programme auspices. Yet, on past experience, however good the proposal, it is unlikely to win support at first attempt, the annual hit rate in the Humanities being generally in single figures. The Programme is also seeking support from the private sector. Sponsorship is being sought for an annual competitive Fellowship, also for more modest scholarships to assist an unspecified number of $\mathrm{PhD}$ candidates and Masters students. Another desideratum is the securing of funds to facilitate short visits by distinguished overseas scholars.

Conferences and workshops will continue to figure prominently in the Programme's calendar, partly because this encourages exchanges between scholars, and partly because such occasions present the work of the Programme to wider publics. ${ }^{60}$ The importance of the latter cannot be underestimated when seeking sponsorship. Two Wellington conferences are planned for 2004. In April there will be a one-day conference devoted to refining the agenda for research on the New Zealand Scots. It is anticipated all those likely to be involved in the mooted Scottish migration project will participate, and that there will also be Australian input. Ideally there will also be Scottish scholars but this depends on ability to secure funding. The responses of bodies such as the British Council to such requests have not been overly generous in recent years. Then, in July, there will be a three-day conference on Ulster/New Zealand migration and cultural transfers. This will be co-sponsored by two University of Ulster units, the Academy for Irish Cultural Heritages and the Institute for Ulster-Scots Studies. Current indications are that local researchers will be joined by up to eight speakers from Ulster. The projected offerings will very be wide-ranging. Later in the year the Programme will be actively supporting the Australian Irish Studies conference, to be held in Melbourne in September.

Beyond the supervision of postgraduate research, university management has resolved that the Programme's teaching should be limited, co-operation with existing departments in the presentation of courses being preferred. ${ }^{61}$ An exception is the proposed summer school on the Irish and Scottish diasporas, which in addition to providing supplementary revenue will also bring ISSP's work to the attention of the interested general public. Depending upon the support forthcoming, the possibility of offering the 
summer school by distance methods may also be explored. The projected postgraduate paper is envisaged as having a very different purpose. The overt intention is to provide prospective researchers in New Zealand and Australasian Irish-Scottish Studies with pertinent research methodologies and familiarity with local research sources. Whether such a paper would be viable in the immediate future has yet to be established. Consideration may also be given to entering into partnerships with overseas providers for the delivery of specialist postgraduate courses online, the Programme providing the New Zealand content, where appropriate, and support services.

The other area in which the Programme is expected to demonstrate leadership is in the development of a publications programme. Although Victoria University has its own university press, over the past half dozen years the Stout Research Centre has on occasion released publications under its own imprint. ${ }^{62}$ The Irish in New Zealand is one such production. This may continue to be an avenue for short run publications, possibly in association with other organisations or institutions. For major monographs, it is likely arrangements with a larger publisher will be pursued, probably but not necessarily with Victoria University Press. A major book currently in the pipeline is Celtic Connections: Irish-Scottish Studies Down Under, which is being jointly edited with Elizabeth Malcolm University of Melbourne. ${ }^{63}$ Loosely based on papers delivered at the 2002 conference, but with a number of commissioned additions, the objective is a reader generally demonstrating current work in Irish-Scottish Studies in Australasia. A target is the production of at least one book a year under the auspices of ISSP. On a more modest scale, it is intended to launch a working papers series, thereby giving exposure to methodological issues and research in progress.

Victoria University of Wellington's Irish-Scottish Studies Programme is still very much in its infancy. While it has clearly moved from good idea status, through concept testing, to fledgling reality, how it will develop in the future has yet to be resolved. That ISSP is filling a gap, serving useful scholarly and community purposes, is evidenced by the enthusiasm with which its activities have been received in New Zealand, and by the keen interest from kindred centres and programmes in other countries. If interest in Irish-Scottish Studies continues to rise in New Zealand, and all indications are that it will, as long as the spirit of co-operation that currently exists between individuals and their institutions continues, ISSP will have facilitatory and initiatory parts to play.

1 Edmund Bohan, “"A Recollection of the Unfortunate Failings of My Own Countrymen”: The Irish in New Zealand Politics, 1860-1880' in Brad Patterson (ed). The Irish in New Zealand: Historical Contexts and Perspectives, Wellington, 2002, pp.53-65. 


\section{Celtic Roots Amidst the Fern: Irish-Scottish Studies in New Zealand}

2 Ibid., p.64.

3 For discussion, see James Belich, Making Peoples, Auckland, 1996, pp.315-7; also James Belich, Paradise Reforged, Auckland, 2001, pp.217-21.

4 Donald Harman Akenson, 'What Did New Zealand do to Scotland and Ireland?', in Brad Patterson (ed.), The Irish in New Zealand: Historical Contexts and Perspectives, Wellington, 2002, p.191.

5 Tom Brooking, "Sharing out the Haggis": The Special Scottish Contribution to New Zealand History', unpublished Bamforth Lecture, 1997, p.1.

6 Donald Harman Akenson, Half the World from Home: Perspectives on the Irish in New Zealand, 1860-1950, Wellington, 1990.

7 New Zealand Official Yearbook 1990, Wellington, 1990, p.158.

8 'Peopling of New Zealand Project': http://www.mch.govt.nz/history/project/people. html.

9 Ibid.

10 Personal communication, J.O.C. Phillips, October 2003.

11 For discussion see R.J. Marolle, 'Immigration' in A.H. McLintock (ed.), An Encylopaedia of New Zealand (Wellington, 1966), pp 130-39.

12 The concept of the 'Atlantic archipelago' was introduced by J.G.A. Pocock; see 'British History: A Plea for a New Subject', New Zealand Journal of History, vol.8, no.1, 1974, pp.3-21. The preliminary figures are available in 'A Home Away from Home: British and Irish Immigration to New Zealand, 1840-1914', http://www.nzhistory.net.nz/Gallery/britnz/index.htm

13 Ibid.

14 http://victoria.lconz.ac.nz

15 http://www.natlib.govt.nz/en/catalogue/index.html\#national

16 Donald Harman Akenson, Half the World from Home: Perspectives on the Irish in New Zealand, 1860-1950, Wellington, 1990.

17 Timothy McIvor, The Rainmaker: A Biography of John Ballance, Journalist and Politician, 1839-1893, Wellington, 1989.

18 A.J. Gray, An Ulster Plantation: the Story of the Katikati Settlement, Dunedin, 1974.

19 Richard P. Davis, Irish Issues in New Zealand Politics, 1868-1922, Dunedin, 1974.

20 Donald Harman Akenson, Small Differences: Irish Catholics and Irish Protestants, 1815-1922. An International Perspective, Montreal \& Kingston, 1988.

21 Patrick O'Farrell, Vanished Kingdoms. Irish in Australia and New Zealand. A Personal Excursion, Kensington, NSW, 1990.

22 Donald Harman Akenson, The Irish Diaspora; A Primer, Toronto, 1996, p.281.

23 Patrick O'Farrell, 'The Irish in Australia and New Zealand, 1791-1870', in W.E. Vaughan (ed.), A New History of Ireland, vol. V, Oxford, 1989, pp.661-81; Patrick O'Farrell, 'The Irish in Australia and New Zealand, 1870-1990', in W.E. Vaughan (ed.), A New History of Ireland, Vol. VI, Oxford, 1996, pp.703-24.

24 Charlotte Macdonald, A Woman of Good Character. Single women as Immigrant Settlers in Nineteenth-Century New Zealand, Wellington, 1990.

25 Edmund Bohan, Edward Stafford: New Zealand's First Statesman, Christchurch, 1994.

26 Edmund Bohan, 'Blest Madman': FitzGerald of Canterbury, Christchurch, 1998.

27 Edmund Bohan, To be a Hero: A Biography of Sir George Grey, Auckland, 1998.

28 R.C.J. Stone, James Dilworth, Auckland, 1995.

29 Anna Rogers, A Lucky Landing: The Story of the Irish In New Zealand, Auckland, 1996.

30 Rory Sweetman, Bishop in the Dock: The Sedition Trial of James Liston, Auckland, 1997. 


\section{Journal of New Zealand Studies}

31 Rory Sweetman, A Fair and Just Solution?: A History of the Integration of Private Schools in New Zealand, Palmerston North, 2002; Faith and Fraternalism: A History of the Hibernian Society in New Zealand, Wellington, 2002.

32 Lyndon Fraser, To Tara via Holyhead: Irish Catholic Immigrants in Nineteenth-Century Christchurch, Auckland, 1997.

33 Lyndon Fraser (ed.), A Distant Shore. Irish Migration and New Zealand Settlement, Dunedin, 2000.

34 Brad Patterson (ed.), The Irish in New Zealand: Historical Contexts and Perspectives, Wellington, 2002.

35 Tom Brooking and Jennie Coleman (eds), The Heather and the Fern: Scottish Migration and New Zealand Settlement, Dunedin, 2003.

36 Tom Brooking, And Captain of Their Souls: An Interpretative Essay on the Life and Times of Captain William Cargill, Dunedin, 1984.

37 Tom Brooking, “Tam McCanny and Kitty Clydesside”: The Scots in New Zealand', in R.A. Cage (ed.), The Scots Abroad: Labour, Capital, Enterprise, London, 1985.

38 Tom Brooking, Lands for the People: The Highland Clearances and the Colonisation of New Zealand. A Biography of John McKenzie, Dunedin, 1996.

39 Jim McAloon, No Idle Rich: The Wealthy of Canterbury and Otago, 1840-1914, Dunedin, 2002.

40 Michael Bassett with Michael King, Tomorrow Comes the Song; A Life of Peter Fraser, Auckland, 2000.

41 G.L. Pearce, The Scots of New Zealand, Auckland, 1976.

42 Maureen Molloy, Those Who Speak to the Heart: The Nova Scotia Scots at Waipu, 1854-1920, Palmerston North, 1991.

43 Susan Butterworth with Graeme Butterworth, Chips Off the Auld Rock: Shetlanders in New Zealand, Wellington, 1997.

44 In mid-2004 a research team led by the writer successfully secured substantial funding from the Royal Society of New Zealand's Marsden Fund to undertake a three-year investigation into the nature and impacts of Scottish migration to New Zealand to 1950. The team includes four New Zealand-based researchers (Brad Patterson, Victoria University of Wellington; Tom Brooking, University of Otago; Jim McAloon, Lincoln University; Rosalind McClean, University of Waikato) and three from the University of Aberdeen's AHRB Centre for Irish and Scottish Studies (Tom Devine, Marjory Harper, Angela McCarthy).

45 For Akenson's agenda see Half the World from Home, pp.193-203; for Brooking's agenda see 'The Most Subtle Scots: A Report on the State of Scottish Studies in New Zealand', in Brad Patterson and Elizabeth Malcolm (eds), Celtic Connections: Irish-Scottish Studies Down Under, forthcoming. Brooking also addresses this question in Brooking and Coleman, The Heather and the Fern, pp.49-65.

46 Table 2 has been compiled from a search of New Zealand university web sites in October 2003.

47 Victoria University of Wellington's proposed 2004/05 Summer School (The Irish and Scots in Australasia) was withdrawn in early 2004, it being decided that the IrishScottish Studies Programme would instead collaborate with the Department of History in the introduction of 300-level papers in 2004/05 (The Irish Diaspora) and 2005/06 (The Scots Abroad). The new approach was a direct outcome of the appointment of a Celtic migration specialist to the University's Chair of History, this increasing the critical teaching mass available.

48 Although the establishment of an endowed Chair in Irish Studies at Otago University was announced in 2004, it has yet to be filled. No further information is available on the proposal to establish a chair at the University of Auckland. 
49 Of the suite of taught courses approved in 2002, one only (Hist 121) will be offered in 2005. The University of Waikato website notes there will be no new intake of students in 2005. There is no indication what the policy will be in subsequent years.

50 Table 3 compiled from the returns of theses and research essays in history completed or in progress in New Zealand universities, published each October in the New Zealand Journal of History, University of Auckland.

51 Rosalind McClean, 'Scottish Emigrants to New Zealand, 1840-1880: Motives, Means and Background', PhD thesis, University of Edinburgh, 1990; Angela McCarthy, " "Seas May Divide": Irish Migration to New Zealand as Portrayed in Personal Correspondence, 1840-1937', PhD thesis, Trinity College, Dublin, 2000.

52 For an account of the origins of the Irish-Scottish Studies Programme, see 'Irish-Scottish Studies Down Under: an Interview with Brad Patterson', in History Now/Te Pae Tawhito o te Wa, vol.10, no.1, 2004, pp.2-4.

53 The establishment of the Stout Research Centre is discussed in Jock Phillips, 'A Window on the Stout Centre: its Stained Glass and Origins', in Stout Centre Review, vol.1, no.4, April 1991.

54 It became evident in the course of the 2000 conference that more researchers were engaged on Irish topics in New Zealand than had been envisaged, and that there was a strong inclination amongst the researchers to network.

55 Val Noone, 'Wellington Connections: Irish and Scots Stories', in Táin, no.27, Oct-Nov 2003, pp.8-9.

56 The Irish-Scottish Studies Programme: A Proposal and Draft Strategic Plan, unpublished paper presented to Vice-Chancellor, Victoria University of Wellington, May 2003.

57 An Advisory committee of eight, including members of Victoria University's Senior management Team and the University Council, was appointed in 2004. It is chaired by Professor Donald McRaild. While at present the Advisory Committee is essentially an 'in-house' organ, wider membership may be considered at a later time.

58 There is already active co-operation between ISSP and the Irish Studies Centre, University of Melbourne, the AHRB Research Centre for Irish and Scottish Studies at the University of Aberdeen, and two units (Institute of Ulster-Scots Studies, Academy for Irish Cultural Heritages) at the University of Ulster. Dialogue has also been initiated with a number of other research institutes and centres in Ireland and Scotland.

59 The 2004 award of NZ\$510,000 from the Marsden Fund is ISSP's greatest external funding success to date, although more modest sums have been secured from both international and New Zealand sources.

60 ISSP's Strategic Plan requires the organisation of at least one major international conference every two years, and the mounting of two one-day seminars/workshops annually.

61 See note 45. It is probable that future undergraduate teaching will be in association with existing departments. The shape of postgraduate courses has yet to be determined.

62 In furtherance of the objective of producing one book a year, a volume of essays was published in association with the Institute of Ulster-Scots Studies in 2004: Brad Patterson (ed.), From Ulster to New Ulster; The 2003 Ulster-New Zealand Lectures, Coleraine and Wellington. A more ambitious collection is scheduled for publication by Four Courts Press in 2005: Brad Patterson (ed.), The Hidden Irish: Ulster-New Zealand Migration and Cultural Transfers, Dublin.

63 www.history.unimelb.edu.au/irish/Website9.htm (accessed Oct. 2003) 